\title{
An Empirical Analysis of the stochastic implications of Stock Price Movements in the Nigerian Capital Market
}

\author{
Ayakeme E. Whisky (PhD) \\ Faculty of Management Sciences, Department of Finance and Banking \\ University of Port-Harcourt, Rivers State, Nigeria, \\ ayakswhisky@yahoo.com
}

\begin{abstract}
The study provides further empirical insight on the behavior of stocks in four selected sectors of the Nigerian economy using the Runs and GARCH techniques to analyze monthly stock data for the period January to December, 2011. The results of the Runs Test do not support random movements of stocks in all the sectors, indicating homoscedasticity. The GARCH estimated model also shows volatility clustering in all the sectors except the Agricultural sector, which implies weak form inefficiency of the Nigerian capital market.
\end{abstract}

Keywords: Randomness; stochastic movements; runs; GARCH; homoscedasticity; heteroscedasticity; Nigeria

\section{INTRODUCTION}

Stock prices are generally presumed to move at random, a characteristic that makes stocks unpredictable, whether they are traded in developed or emerging capital markets. In other words, prices of stocks change almost every minute relative to the demand for them. Despite this expected trend some studies have indicated that stock prices are homogenous, showing evidence of consistency over a definite time horizon. Thus, the hypothesis of stochastic or random stock movements has continued to elicit curious interest, generating considerable questions about its efficacy in capital markets, including Nigeria.

When stock prices display stochastic tendency in a market, we say such market is weak form efficient and therefore, investors cannot outperform the market through speculative activities or predicting changes in prices to take advantage of other investors. The controversy over the random movement of stock prices and the attendant efficiency of the capital markets in the weak form have evoked a number of empirical studies that support the efficient market theory (Pele and Voineagu, 2008; Adelegan, 2009; Okpara, 2010). Similarly, there have also been studies that have given empirical validity against the efficient market theory, suggesting that stock prices are homogenous and not stochastic (Khan and Ikam, 2010; Nwosa and Oseni, 2011).

As an emerging market, the outcome of empirical investigations into the efficiency of the capital market has thrown up conflicting results in Nigeria. While the earlier works including Ayadi (1984) have received considerable endorsement and support from subsequent researches that stock prices in the Nigerian capital market move stochastically, recent researches however posit that previous prices can successfully predict current stock prices. The answer to the question on whether stock prices move randomly or markets are weak form efficient over time and across capital markets has continued to attract interesting scholarship necessitating fresh investigation. We are thus motivated to contribute to this ever-refreshing 
debate. Thus, the primary concern of this study is to examine the empirical validity of the random work hypothesis and if the stochastic behavior of stocks is empirically in sync with the efficient market hypothesis in the Nigerian capital market. The rest of the paper is presented as follows: literature review, methodology and data, results, conclusion and recommendations.

\section{LITERATURE REVIEW}

Pele and Voineagu (2008) investigated the Romanian capital market to determine its efficiency by adopting a model for long-horizons returns which decomposes the time series of prices natural logarithms into the sum of a random walk and a stationary component and evaluated the top 10 stocks that account for $60 \%$ of market capitalization. Relying on the parameters of the autoregressive process where the market is presumed efficient if $p=1$ and inefficient if $p$ $=/ 1$, they concluded that the Romanian Capital market was efficient in the weak form. They noted that the long-term stock price dynamics are influenced to a large extent by the actions of some potential short term and general factors. As a consequence they cannot reject the weak form efficiency hypothesis.

Khan and Ikram (2010) investigated the impact of foreign institutional investors on the Indian capital market with respect to the influence of publicly available information on asset returns, whether it is possible to capitalize on such information to earn excess return. Using data from


adopted correlation and regression techniques and found that there is a significant impact on Indian capital market by the activities of foreign institutional investors. It concluded that the Indian capital market is semi - strong form efficient as the activities of the foreign institutional investment (FII) verily create instant reaction in the market, thus no investor can outperform the market.

Grossman and Stiglitz (1980) examined the impossibility of informationally efficient markets by calculating the expected utility of the informed and the expected utility of the uninformed investor. They assumed that both investors are identical ex-ante, the only difference is whether the informed and uninformed have spent money to obtain information. Extending the noisy rational expectations model introduced by Robert Lucas which Jerry Green applied to the study of information flows, the authors assumed a two asset model (a safe asset yielding a return and a risky asset) and two types of individuals, those who are informed traders and those who are uninformed traders. Applying Constant Absolute Risk- Aversion Model (CARM) to estimate budget constraints of an investor, individual's utility maximization, equilibrium price distribution, existence of equilibrium and characterization theorem, the authors concluded that it is impossible for capital markets to be informationally efficient.

Jenning and Stark (1985) conducted an investigation into the speed of stock price adjustment to new information, using PW stochastic process tests on how stratified sample data of last forecast after the announcement of earnings estimates of the Standard and Poor's Corporation and 40 other professional security analyst. The study revealed that announcements with anticipated high information content were associated with price adjustment processes, while those with low information content showed less evidence of anticipatory price movement, indicating price influences with high content announcement.

In a different market, Mobarek and Keasey (2000) investigated the Dhaka Stock Market of Bangladesh with a view to determining whether it is weak-form efficient as an emerging market. They adopted parametric tests of auto-regression and auto-regressive-integratedmoving average (ARIMA) to estimate daily market returns covering a sample period of $1^{\text {st }}$ 
January, 1988 to $31^{\text {st }}$ December, 1997 and also non-parametric tests of koglomorov-Smirnov goodness of fit test and runs test and concluded that the Dhaka Stock Market of Bangladesh is not weak-form efficient. Hence the position that the stock prices move randomly is debunked in this market. A review of studies conducted in Nigeria showed mix conclusions as well.

Ayadi (1984) examined whether stock prices in Nigeria follow a predictable path by using Monday closing prices of 30 securities of the Nigerian stock exchange between $1^{\text {st January, }}$ 1977 and 31 ${ }^{\text {st }}$ December, 1980. Adopting the estimation models of Wald-Wolfwitz and runs non-parametric tests, the results show that share price movements in Nigeria follow a random walk.

Adelegan (2009) investigated whether the Nigerian capital market is efficient in the semistrong form with respect to reactions to dividend announcement. The study used share price cutting across the pre and post liberalization regimes, concentrating on the 3-day, 21-day and 61-day event windows in the short-run for the period 1990 to 1999. In evaluating the speed of adjustment to announcements of dividend payments and omissions for 742 announcement dates. The study found that the Nigerian capital market is not semi-strong efficient.

Recently, Okpara (2010) in further investigating the random walk hypothesis in the Nigerian stock market used end of month averages of 121 securities listed in the NSE for the period 1984 to 2006. The study adopted the non-parametric test, runs test and the more scientific test, autocorrelation involving correlograms and the Ljung - Box Q statistics. The study confirmed that the Nigerian stock market is weak form efficient, thus corroborating earlier work of Ayadi (1984).

Concerned over the contrasting results of studies on the Nigerian capital market which at a time concluded that the market was efficient in the weak form and later that it was efficient in the strong form, particularly at a time when improved infrastructure should have impacted the information flow and enhanced performance, Emenike (2008) investigated the Nigerian capital market to determine whether it is efficient across time. The study was interested in knowing if efficiency could change over time. Using the monthly All Share Index (ASI) of the NSE, the study considered three distinct periods beginning from January 1985 to December 1992; January 1993 to December 1999 and January 2000 to December 2007. The statistical tools of normality test and runs test were used. The study showed that the Nigerian capital market is not efficient in the weak form across time. This however contradicts some previous studies.

For instance, Samuel and Yacout (1981) was reported in Adelegan (2009) to have used serial correlation test to examine weekly prices of 21 Nigerian firms listed in the Nigerian stock exchange from July 1977 to July 1979 and concluded that stock price changes are not serially correlated but follow a random walk, thereby accepting the weak-form market efficiency.

Olowe (1999) was reported by Okpara (2008) to have used the correlation analysis of monthly returns data of 59 individual stocks listed in the NSE to examine the weak form efficiency of the NSE and corroborated the findings of Samuel and Yacout (1981) and Ayadi (1984).

In their study, Ojo and Azeez (2012) conducted an examination to determine whether the Nigerian capital market is efficient in the strong form. Employing the econometric tool of autoregressive heteroscedasticity (ARCH) introduced by Engel (1982) and the Generalized Autoregressive Conditional Heteroscedasticity (GARCH) introduced by Bollerslev (1986) to estimate data obtained from the NSE covering the period 1986 to 2010 the study indicated that the Nigerian capital market is efficient in the weak form. 
Ajao and Osayuwu (2012) investigated the weak form efficiency of the Nigerian capital market using serial correlation technique to determine the independence of successive price movement and runs test to investigate the randomness of share price movement. Month end value data of the All Share Index (ASI) from the Nigerian stock exchange covering the period 2001 to 2010 was used for the analysis. The study concluded that prices of stock traded in the Nigerian capital market are random, thus giving fillip to the Random Walk Theory, which of course implies that the market is efficient in the weak form.

But the work of Nwosa and Oseni (2011) that examined the efficiency of the Nigerian stock market, for the period 1986 to 2010, using serial autocorrelation and regression analysis revealed that the Nigerian capital market is informationally inefficient. This means that stock prices do not exhibit random walk. According to their work, the lag value of stock price is significant, implying that previous stock prices can successfully predict current stock prices.

Therefore in an attempt to further investigate the form of efficiency of the Nigerian capital market, against the backdrop of conflicting findings of previous research works, the study decided to adopt detailed sectoral investigations with a view to establishing whether the findings in each of the sectors will correlate the overall market position.

\section{METHODOLOGY}

In this study, we used the non-parametric technique of Runs test in determining whether stock prices in the Nigerian capital market move at random based on its frequently varied use in previous researches, particularly in emerging markets (Vulic; Emenike, 2008; Barnes, 1986; Claessens, et al, 1995; Dickinson and Muragu, 1994; Simon and Larvea, 2004; Rahman and Hossain, 2006 as reported in Emenike, 2008). A run is defined as a succession of one or more identical symbols, which are followed and preceded by a different symbol or no symbol at all (Wang, 2003). As Gujarati and Sangeetha (2007) posited, while too many runs indicate negative correlation too few runs may suggest positive autocorrelation. In undertaking the runs test Gujarati (2007) expressed the Mean, Variance and expected approximated probability as shown below:

$$
\begin{aligned}
& \text { 'Mean: } E(R)=\frac{2 \mathrm{~N}_{1} \mathrm{~N}_{2}}{\mathrm{~N}}+1 \\
& \text { Variance: } \quad \sigma^{2}=\underbrace{2 \mathrm{~N}_{1} \mathrm{~N}_{2}\left(2 \mathrm{~N}_{1} \mathrm{~N}_{2-}\right)}_{(\mathrm{N}) 2(\mathrm{~N}-1)} \\
& \operatorname{prob}\left[E(\mathrm{R})-196 \sigma_{\mathrm{R}} \leq \mathrm{R} \leq E(\mathrm{R})+1.96 \sigma_{\mathrm{R}}\right]=0.95
\end{aligned}
$$

The Z statistics gives the probability of the difference between the actual and expected runs.

Where:

$$
Z=\frac{R-M}{\sigma^{2} R}
$$

$\mathrm{N}$ : total number of observation $=\mathrm{N} 1+\mathrm{N} 2$

$\mathrm{N} 1=$ number of + symbols (i.e + residuals)

$\mathrm{N} 2$ = number of - symbols (i.e - residuals)

$\mathrm{R}=$ number of runs 
A further application of the parametric test, GARCH, which allows for time variant conditional variance and nonlinearities in generating mechanism (Okpara, 2010) is used to corroborate the findings of the Runs test. Adapting Brook's (2008) presentation, the GARCH model, which can be used to interpret the current fitted variance and information about volatility during the previous period, is expressed as:

$$
\sigma^{2}=\alpha_{0}+\alpha_{1} \varepsilon^{2}-1+\beta \sigma^{2}-1
$$

Where:

$\sigma^{2}{ }_{\mathrm{t}}=$ Conditional Variance

$\alpha_{0}=$ Constant

$\alpha_{1} \varepsilon^{2} \mathrm{t}-1=$ Information about volatility during the previous period

$\beta \sigma^{2}$-1 $=$ Fitted variance during the previous period

\section{DATA}

Data for this study, the daily stock prices, sourced from the website of Central Securities and Clearing system (http:/www.cscsnigerialtd.com), was downloaded in Microsoft excel format and converted into monthly balances. We further sourced the monthly balances of the Nigerian Stock Exchange All Shares index (ASI) from the fat book of the Nigerian Stock Exchange.

\section{Application of Runs Test for the Random Movement of Agricultural Sector Stocks}

Table-1 Run Test Results

\begin{tabular}{|l|c|}
\hline & RS \\
\hline Test Value $^{a}$ & 0.2 \\
Cases < Test Value & 36 \\
Cases >=Test Value & 36 \\
Total Cases & 72 \\
Numbers of Runs & 42 \\
Z & 1.187 \\
Asymp. Sig.(2-tailed & .235 \\
\multicolumn{2}{|c|}{} \\
a: Median \\
Source: Author's Computation
\end{tabular}

Table-1 reports the test of the random movement of returns in the agricultural sector based on Runs test Technique. The results show that observed z- statistics value of 1.187 is less that the critical value of 1.645. Therefore, we cannot reject the null hypothesis that the series of returns do not move randomly. This in order words means that the agricultural sector of the stock market cannot be said not to have memory.

\section{Application of GARCH in Testing for Agricultural Sector Stocks Random Movements}

Table-2. The Result of the GARCH Model

\begin{tabular}{|c|c|c|c|c|}
\hline Variable & Coefficient & std. Error & z-Statistic & Prob. \\
\hline VOLRS & -7.339240 & 7.250817 & -1.012195 & 0.3114 \\
\hline RESID(-1) $\cdot 2$ & $\mathbf{0 . 1 0 4 4 8 7}$ & $\mathbf{0 . 1 7 2 6 4 8}$ & $\mathbf{0 . 6 0 5 2 0 5}$ & $\mathbf{0 . 5 4 5 0}$ \\
\hline GARCH(-1) & $\mathbf{0 . 1 5 8 3 9 2}$ & $\mathbf{0 . 8 1 6 3 7 4}$ & $\mathbf{0 . 1 9 4 0 1 8}$ & $\mathbf{0 . 8 4 6 2}$ \\
\hline
\end{tabular}

Source: Author's computation

The results in table 4.2 above show that there is no significant relationship between return and volatility given that the $\mathrm{z}$ - critical of 1.645 which is greater than the observed $\mathrm{z}$-statistics at 
value of -1.012195 . The observed negative z-statistics value is further indicative of an inverse relationship between volatility and returns. There is also no volatility clustering and no presence of ARCH or GARCH since the combined value of the coefficients is only 0.258 .

The Cause and Effect of Volatility and Returns in the Agricultural sector

Table-3 Granger Causality Test Results

\begin{tabular}{|c|c|c|c|}
\hline Null Hypothesis: & Obs & F-Statistics & Probs \\
\hline $\begin{array}{c}\text { VOLRS does not } \\
\text { Granger Cause RS }\end{array}$ & 70 & 0.63747 & 0.5319 \\
\hline $\begin{array}{c}\text { RS does not Granger } \\
\text { Cause VOLRS }\end{array}$ & & 3.21141 & 0.0468 \\
\hline
\end{tabular}

Source: Author's computation

The study observed that volatility does not Granger cause return since the critical F- statistics value of 2.37 is greater that the observed value of 0.63747 . Accordingly, we cannot reject the null hypothesis. However returns does Granger cause volatility as the null hypothesis is rejected since the calculated F-statistic value of 3.2114 is greater that the critical value. The results show a unidirectional relationship.

From the results above, particularly the runs test, the study shows investors can conveniently use previous returns to predict future returns. This certainly confers advantage on market participants and analysts who indulges in the use of past data to predict future outcome to outperform the market since the series of returns do not have stochastic movement. The study further shows that the risk - return relationship is not only insignificant but also inverse in the agricultural sector. Investment in agriculture though preferred but usually not attractive because of perceived high volatility. Therefore performance of the agricultural sector may not have been strictly defined by market forces but due to government intervention. Given the employment potentials of the sector, government's intermittent interventions in forms of grants and subsidies constitute the occasional stimulus to drive the sector. The volatility and returns relationship in the mean variance equation of the GARCH Model further elucidates that the agricultural sector of the Nigerian capital market is not efficient in the weak form.

\section{Application of Runs Test for the Random Movement of Automobile Sector Stocks}

Table-4. Runs Test Results

\begin{tabular}{|l|l|}
\hline & RS \\
\hline Test Value $^{\mathrm{a}}$ & .00 \\
Cases $<$ Test Value & 32 \\
Cases $>=$ Test Value & 40 \\
Total Cases & 72 \\
Number of Runs & 29 \\
Z & 1.816 \\
Asymp. Sig. (2-tailed) & .069 \\
\hline
\end{tabular}

a. Median

Source: Author's Computation

At an observed z- value of -1.816, which is less than the critical value of 1.645 at $5 \%$ degree of freedom, table 4.4 shows that the series of returns do not move randomly. This means there is 
presence of runs or the market has memory. Therefore the impact of previous returns on current returns cannot be ruled out.

\section{Application of GARCH in Testing for Automobile Sector Stocks Random Movements}

Table-5. The Results of the GARCH Model

\begin{tabular}{|c|c|c|c|c|}
\hline Variable & Coefficient & std. Error & z-Statistic & Prob. \\
\hline VOLRS & 4.321934 & 0.102205 & 42.28694 & 0.0000 \\
\hline RESID $(-1)^{\wedge} 2$ & -0.043669 & 0.003937 & -11.09199 & 0.0000 \\
\hline GARCH(-1) & 1.026246 & 0.006165 & 166.4500 & 0.0000 \\
\hline
\end{tabular}

From the mean equation in table 4.5 there is a positive relationship between return and volatility given the Z-statistics of 42.29. Given that the combined coefficients in the ARCH and GARCH in the variance equation are approximation 1, the study shows that there was volatility clustering of the returns. The presence of ARCH and GARCH further showed that there was no randomness in the movement of the returns.

The Cause and Effect of volatility and Returns in the Automobile Sector

Table-6. Granger Causality Test Results

\begin{tabular}{|l|c|c|c|}
\hline \multicolumn{1}{|c|}{ Null Hypothesis } & obs & F-statistic & Prob. \\
\hline $\begin{array}{l}\text { VOLRS does not } \\
\text { Granger cause RS }\end{array}$ & 70 & 0.95175 & 0.3914 \\
\hline $\begin{array}{l}\text { RS does not Granger } \\
\text { Cause VOLRS }\end{array}$ & & 0.82379 & 0.4433 \\
\hline
\end{tabular}

Source: Author's computation

The calculated F-statistics values in table 4.6 are both less than the critical value of 2.37 . We do not therefore reject the hypothesis that neither volatility nor returns Granger cause the other in the automobile sector. This finding is however not in tandem with theory.

\section{Application of Runs Test for the random Movement of Banking sector stocks.}

Table-7. Run Test Results

\begin{tabular}{|l|c|}
\hline & RS \\
\hline Test Value $^{\text {a }}$ & -.02 \\
Cases<Test Value & 36 \\
Cases $>=$ Test Value & 36 \\
Total Cases & 72 \\
Number of Runs & 27 \\
Z & -2.374 \\
Asymp. Sig. (2-tailed) & .018 \\
\hline
\end{tabular}

From the runs test in table-7, we observed z- statistics value of -2.374 is less than the critical value of 1.6449 .

We cannot therefore reject the null hypothesis that the series of returns do not move randomly. Infact, the results showed there was presence of runs and the market has memory. Previous returns were thus not independent of current returns. 


\section{Application of GARCH in Testing for Banking Sector Stocks Random Movements.}

Table-8. The Results of the GARCH Model

\begin{tabular}{|c|c|c|c|c|}
\hline Variable & Coefficient & std. Error & z-Statistic & Prob. \\
\hline VOLRS & 0.303111 & 1.136815 & 0.266632 & 0.800 \\
\hline RESID(-1)^ 2 & 0.787034 & 0.390358 & 2.016186 & 0.044 \\
\hline GARCH(-1) & 0.542846 & 0.127496 & 4.257755 & 0.000 \\
\hline
\end{tabular}

Source: Author's computation

The mean equation in table 8 examines the relationship between volatility and return. It reveals that there is positive and significant relationship between volatility and returns during the study period. In the variance equation, we observed volatility clustering and the presence of ARCH and GARCH since the sum of the coefficients approximates 1.32.

\section{The Cause and Effect of Volatility and Returns in the banking Sector}

Table-9. Granger Causality Test Returns

\begin{tabular}{|c|c|c|c|}
\hline Null Hypothesis & obs. & F-statistic & Prob. \\
\hline $\begin{array}{c}\text { VOLRS does not } \\
\text { Granger cause RS }\end{array}$ & 70 & 0.37564 & 0.688 \\
\hline $\begin{array}{c}\text { RS does not Granger } \\
\text { Cause VOLRS }\end{array}$ & & 16.2641 & $0 . E-06$ \\
\hline
\end{tabular}

Source: Author's Computation

We noticed that the calculated F-statistics in the test of volatility compared to the critical value of 2.37 suggests that we cannot reject the null hypothesis that volatility does not Granger Cause return. This however is not applicable to the test of returns, which calculated F-statistics is greater than the critical, thus indicating that we can reject the null hypothesis. The unidirectional relationship between volatility and returns in the banking sector thus indicates that investors can use returns to predict volatility. In other words, where the returns of an asset of this sector is noticed to be high it portends that such asset has high risk and when the return is low, it presupposes low risk.

\section{Application of Runs Test for the Random Movement of Beverages Sector Stocks}

Table-10. Run Test Results

\begin{tabular}{|l|c|}
\hline & RS \\
\hline Test Value & \\
Cases<Test Value & .00 \\
Cases>=Test Value & 36 \\
Total Cases & 36 \\
Number of Runs & 72 \\
Z & 29 \\
Asymp. Sig. (2-tailed) & -1.899 \\
& .058 \\
\hline a. Median
\end{tabular}

The results from the runs test in table 4.10 shows that the calculated z-statistic value of -1.899 is less than the critical value of 1.645 , we cannot therefore reject the null hypothesis that the series of returns do not move randomly. It means investors in this sector can conveniently predict future returns with previous returns. This indicates weak form inefficiency. 


\section{Application of GARCH in Testing for Beverages Sector Random Movements}

Table-11. The Results of the GARCH Model

\begin{tabular}{|c|c|c|c|c|}
\hline Variable & Coefficient & std. Error & z-Statistic & Prob. \\
\hline VOLRS & 0.640794 & 1.815452 & 0.352967 & 0.7241 \\
\hline RESID(-1)^ 2 & 0.515304 & 0.258933 & 1.990110 & 0.0466 \\
\hline GARCH(-1) & 0.565833 & 0.123910 & 4.566487 & 0.0000 \\
\hline
\end{tabular}

The mean equation result in table 4.11 above indicates that there is positive relationship between volatility and returns, which is significant. The volatility coefficient of 0.640 shows that volatility could influence returns up to $64 \%$. The variance equation also show that there is the presence ARCH and GARCH, given that the sum of coefficients is greater than 1 . This means there was volatility clustering or pooling of the returns and this indicates autocorrelation.

\section{The Cause and Effect of Volatility and Returns in the Beverages Sector}

Table-12. Granger Causality Test Results

\begin{tabular}{|c|c|c|c|}
\hline Null Hypothesis & obs. & F-statistic & Prob. \\
\hline $\begin{array}{c}\text { VOLRS does not } \\
\text { Granger cause RS }\end{array}$ & $\mathbf{7 0}$ & $\mathbf{1 . 2 5 8 1 2}$ & $\mathbf{0 . 2 9 1 0}$ \\
\hline $\begin{array}{c}\text { RS does not Granger } \\
\text { Cause VOLRS }\end{array}$ & & 16.2641 & $3 . \mathrm{E}-15$ \\
\hline
\end{tabular}

Source: Author's computation

While we do not reject the null hypothesis that volatility does not Granger cause returns since the observed F-statistics value is less that the critical, we do reject the null hypothesis that returns does not Granger cause volatility. There is therefore a unidirectional relationship between volatility and returns in the beverages sector. This finding corroborates the results of the banking sector where we discovered that returns can be used to predict the riskiness of assets.

\section{DISCUSSION OF FINDINGS}

The GARCH model, as an estimation technique for time variant conditional variance and nonlinearities in generating mechanism, provides good fit for stock returns volatility and hence the results obtained could be reliable. However, the observed volatility clustering and the presence of $\mathrm{ARCH}$ and GARCH in the automobile, banking and beverages sectors indicate interdependency of the series of returns. Because even where the variance equation of the GARCH indicate volatility clustering, the returns could be deterministic in nature, lending credence to possible linear dependency of previous returns and current returns. These situations may not have been peculiar to the Nigerian capital market, as an emerging market that is fraught with the challenges of effective information asymmetry and ethical practices until recently.

The study notes that outside the agricultural sector there is positive and significant relationship between risk and return which is in sync with theoretical construct. The off-curve finding in the agricultural sector, as noted previously can be explained from the perspective of its high-risk nature that usually repels investors in the normal course of business. In other words, what attracts investors to the agricultural sector is the promise of high returns characterized by direct government intervention in most cases. For instance since the inception of the present administration in 2010, so much attention has been given to the 
agricultural sector because of government's determination to make the agricultural sector the hub of the economy.

Nonetheless, the results of the other sectors that show a unidirectional relationship between volatility and returns, other than being in sync with theory, has remained the fulcrum of finance theory. This is more so that the reward to risk is the expected returns, which either offers commensurate benefits or earns a premium. It would serve as a disincentive if investors are not promised higher returns for investing in assets with risky characteristics. It thus infers that when investors invest on assets that are risky they are assured of higher returns since risk (volatility) move in the same direction.

\section{CONCLUSION AND RECOMMENDATIONS}

The pattern of stock price movements in the four sub-sectors of the Nigerian capital market namely, agricultural, automobile, banking and beverages sectors, were investigated using the Runs and GARCH techniques for the period January 2006 to December 2011. The Runs test results reveal that stocks of the selected sectors do not move at random, indicating that stocks in these sectors do not manifest stochastic behavior. In other words, these sectors in the Nigerian capital market demonstrate weak form inefficiency. Looking at the results of the GARCH mean model at lag one so as to further amplify our finding, we discovered that with the exception of the Agricultural Sector, stock returns demonstrate volatility clustering,and thisindicates autocorrelation and weak-form inefficiency(Emenike, 2008). Thus, the results of the Runs test and GARCH technique seemingly suggest that stock prices in these sectors of the market do not show stochastic behavior and hence cannot be said to be efficient in the weak form.

The findings portend a situation where investors, with clear analytical capacity can predict future returns from previous returns and can make substantial gains by investing in those sectors of the Nigerian capital market. A critical study of the risk profile of the sectors, particularly the sectors with positive and unidirectional risk-return relationship presents opportunities for investors to leverage since there is the likelihood of earning higher returns in excess of the market average in those sectors. But this would require regular monitoring as the dynamics of the economy and the market could change a given asset characteristics overtime.

We therefore recommend that there should be proper strengthening of policy framework as well as improved communication infrastructure to facilitate information dissemination to investors in these sectors. This will contribute to repositioning the entire operational framework of the market in pursuit of its fundamental mandate of advancing the economic frontiers and growth of the country.

\section{References}

Adams, A., Bloomfield, D., Booth, P. and England, P. (1993).Investment mathematics and statistics. Kluwer Academic publishers Group, Norwell, Massachusetts, USA.

Adelegan, O. J. (2009). Price reactions to dividend announcements on the Nigerian capital market. AERC Research Paper 188. Retrieved from price reactions to Dividend Announcement NCM. Pdf - Adobe Reader.

Ajao, M. G. \& Osayuwu, R. (2012). Testing the weak form of efficient market hypothesis in Nigerian capital market. Accounting and Finance Research, Vol. 1(1), 169-179. Retrieved from http://www.sciedu.ca/afr.

Ayadi O. (1984). The random walk hypothesis and behavior of share prices in Nigeria. The Nigerian journal of Economics and social Studies, 26(1), 57-71. 
Brooks, C. (2008). Introductory Econometrics for finance, (2 ${ }^{\text {nd }}$ ed.). Cambridge, UK, Cambridge University Press.

Dogu, M., Karacaer, S., \& Karan, M. B (2010).Empirical testing of insider trading in the lstanbul stock exchange. International Research Journal of Finance and Economics, 15, 97-107. Retrieved from http://www.eurojournals.com/finance.htm

Echekoba, F.N. \&Ezu, G. K. (2012). Effective Market Hypothesis: A historical perspective (A study of Nigerian capital market). Kuwait Chapter of Arabian Journal of Business and Management Review, 1(8), 76-86.

Emenike, K. O. (2008). Efficiency across time: Evidence from the Nigerian Stock exchange. Retrieved from http://mpra.ub.muenchen.de/22901/MPRA Paper No. 22901, posted 29, May 2010/19:55

Fama, E. F.(1965) "Random walks in stock market prices". Journal of Business. Retrieved from http://www.chicagobooth.edu/facaulty/selected papers/sp16.pdf Grossman,S.j. \&Stiglitz, J. E. (1980). ON THE IMPOSSIBILITY of informational efficient markets. The American Economic Review, 70(3), 393-408.

Gujarati, D. N. Sangeetha (2007). Basic Econometrics. (4th ed.). Tata Mcgraw-Hill Publishing Company Ltd., New Delhi.

Jennings, R. \& Starks, L. (1985). Information content and the speed of stock price adjustment. Journal of Accounting Research, 23(1), 336-350.

Jensen, M. C. (1978).Some anomalous evidence regarding market efficiency. Journal of finance Economics, 6(2/3), 95-101.

Khan, A. Q. \&Ikram, S. (2010). Testing semi-strong form of efficient market hypothesis in relation to the impart of foreign institutional investors" (FII) investments on Indian capital market. International Journal of Trade, Economics and Finance, 1(4), 373-379.

Maheu, J. M.\& McCurdy, T. H. (2007). Components of market risk and return. Journal of Financial Econometrics, 5(4), 560-590.

Mobarek, A. \& keasykeavin (2000). Weak form efficiency of an emerging market: evidence from Dhaka stock market of Bangladesh. E-m-h.org/Moke00.pdf.

Nwezeaku, N. C. and Okpara, G. C. (2010) the effects of financial deepening on stock market returns and volatility: evidence from Nigeria. Internal Research Journal of Finance and Economics, 40 (2010).

http:www:eurojournals.com/finance.htm

Nwosa, P. I. and Oseni , I. O. (2011). Efficient market hypothesis and Nigerian stock market. Research journal of Finance and Accounting, 2(12): 38-46.

Ogege, S. \& Ezike J. E. (2012). THE Nigerian capital market and economic development: A critical appraisal. International Business Research, 5(8), 228-236.

Oke, M. O. \& Azeez B. A. (2012). A test of strong-form efficiency of the Nigerian Capital Market. Business System Review, 1(1), 10-26. Retrieved from http://www.business-systems-review.Org.

Okpara, G. C. (2010). Stock market prices and the random walk hypothesis: Further evidence from Garch model. The International Journal of Applied Economic and Finance, 4(2), 62-66.

Olowe, R. A. (1998). "stock splits and efficiency of the Nigerian stock market”. African Review of Money, Finance and Banking.www.jstor.org/stable/23026306

Pele, D. T. \&Voineagu V. (2008). Testing market efficiency via decomposition of stock return: Application to Romanian capital market. Romanian Journal of Economic Forecasting, (3), 63-79.

Seyhun H. N. (1986). Insiders' profit, cost of trading and market efficiency. Journal of Financial Economics, vol. 16: 189-212 
Whisky, A. E. (2014); An Empirical Analysis of the stochastic implications of Stock Price Movements in the Nigerian Capital Market. Archives of Business Research, 2(5), 57-68

Wang, Y (2003), “Nonparametric tests for randomness”, ECE 461 Project Report. WWW.ifp.illinois.edu/ywang11/paper/ECE461Proj.pdf-United states.

Ziobrowski, A. J., W., Cheng, P. and Ziobrowski B. J. (2011). Abnormal returns from the common stock investment of members of the U.S. House of Representatives. Business and Politics.

13(1).http://www.bepress.com/bap/vol13/iss1/art4 